\title{
Social Business Responsibility: The 'Magarpatta' Way
}

\author{
M. Kanchan ${ }^{1}$ \\ ${ }^{1}$ Centre for Leadership, Innovation and Change, Indian School of Business, Hyderabad, India \\ Correspondence: M. Kanchan, Centre for Leadership, Innovation and Change, Indian School of Business, \\ Hyderabad, India. Tel: 91-995-110-0145. E-mail: kanchanherlekar@yahoo.co.in
}

\author{
Received: December 27, 2012 Accepted: January 30, 2013 Online Published: April 24, 2013 \\ doi:10.5539/par.v2n1p53 \\ URL: http://dx.doi.org/10.5539/par.v2n1p53
}

\begin{abstract}
This case deals with the win-win situation of the social enterprise model of business. The case focuses on the aspect that the economic aspect of maximizing wealth for the shareholders can be integrated with the social objective of 'Doing good'. The case also deals with the leadership qualities and vision to improve the living standards of not only the farmer-turned entrepreneur community but generating more employment for other stakeholders while taking heed of environmental issues like greening the environment, conserving energy and waste recycling. In short, this social business entrepreneurship case showcases how a threat could be turned into an opportunity for sustainability.
\end{abstract}

Keywords: emerging economy, social business enterprise, leadership, sustainability

\section{Introduction}

The difficulty arises in defining and capturing the meaning and essence of social responsibility. Koutilya, the $4^{\text {th }}$ century B.C. political economist in India advocated business with a moral lining which reveals the origins of social responsibility. In India, even a quarter century ago, a corporation's social objectives were narrow and its activities, sporadic and voluntary. But in the present era, the scope and the outcomes have taken a different dimension to include several stakeholders both active and passive.

It has been seen and heard that organizations like nations take pride in their contribution towards social responsibility. Their activities could take one or more forms. Some call it philanthropy, some corporate citizenship and many others business strategy. Whatever may be the form, the impact is often felt by a wider spectrum of society, more often the under privileged. Though the term 'social responsibility' is frequently referred in connection with a corporate body, it is equally applicable to any other entity. Today, social responsibility, corporate or otherwise has emerged as a topic for discussion both in board rooms and classrooms.

OECD has prescribed the four tenets of corporate governance which form its pillars; Transparency, Accountability, Responsibility and Fairness. Responsibility includes social responsibility to all the stakeholders. While World Commission on Environment and Development in its report refers to sustainable development as 'development that meets the needs of the present generation without compromising the ability of the future generations to meet their own needs', World Business Council for Sustainable Development defines Corporate Social Responsibility (CSR) as "The continuing commitment by business to behave ethically and contribute to economic development while improving the quality of life of the workforce and their families as well as of the local community and society at large." Kofi Annan the former UN Secretary-General in his speech in Davos referred to it as "the human face of corporations".

Taking the concept of social responsibility further, it is seen that the responsibility of being a good citizen, corporate or otherwise lies both with the Government and other private bodies too. A new form of business enterprise is the social business enterprise which follows the model of doing good both economically and socially. Austin, Stevenson and Wei-Skillern (2006) define social entrepreneurship as "innovative value creating activity that can occur within or across the non-profit, business or Government sectors." Thompson and Doherty (2006) add that social organizations are those seeking business solutions to social problems. The central driver for social entrepreneurship is the social problem being addressed and comprises of three essential components viz. response to market failures, transformative innovation and financial sustainability (Noruzi, Westover, Rahimi, 2010). 
Defourny and Nyssens (2010) have differentiated between two schools of thought by separating them as 'Earned-Income' School of thought for commercial non-profit approach and 'Mission-driven' business approach which embraces all forms of business initiatives.

\section{The Beginning}

Although such responsibility has been prevalent in private enterprises in India for a long time before its independence, they were few and far between. The traditional thoughts and opinions of what constituted social responsibility always pointed to an activity over and above their economic activity without any expectation of financial gains. Sometimes these activities have had a glimpse of religious leaning too. It frequently took the guise of 'philanthropy'. But looking deeper into the subject, such 'philanthropy' was generally an act of an individual promoter with his personal wealth and not with the wealth of the organization. But these instances were not the rule. There were and continue to be well established business houses with investments made in non-business activities with long-term objectives.

Corporate Social Responsibility took a formal shape when India after independence in 1947 made a serious attempt to industrialize the economy with the Five-Year Plans. These Plans during the then Prime Minister Nehru's regime were the outcome of the influence of the Indo-Russian political friendship. The industrialization took shape wherein industries were established in the private sector, public sector or joint sector of both private players and the Government.

The reasons for which Public Sector Enterprises (PSE) were established were several; the investment in assets and equipment were very high and the private players were unable to garner the required amount of resources and skills. Certain essential industries from a strategic view point like defense and nuclear power and oil were required to be owned solely by the government. But equally important were the social objectives of employment creation and overall development apart from the primary objective of being profitable. It thus had the dual objectives of being economically viable and socially responsible.

Though the PSEs have undertaken different forms either as purely government owned, statutory bodies or as a majority shareholder, the outcome has not been very different. Over time, corporate responsibility came to be synonymous with PSEs in India. With the protective umbrella of the Government both in the market and pricing, their financial objective was thrust to the background and the social objective took precedent. With ever increasing social costs and a steadily declining profitability, corporate responsibility no longer held the same essence as it did before.

\subsection{India's Freedom from Protection}

As a solution to its faulty balance of payments and a poorly developed debt and money market, India opened its doors to multinationals with its new economic policy in 1991 and abolishing its licensing regime. Indian corporations had to fight their way to stay afloat in the market. Deregulation emphasized the need for companies to extend their focus beyond wealth maximization to shareholders to include other societal stakeholders. But in a market-driven economy, any activity, for-profit or not-for-profit necessitates a positive return on its investment and the mark of a true corporate responsibility activity is that it should be self- sufficient and sustainable in the long run. The 'real' investment of a company in social responsibility must typically consist of capital invested upfront, at the beginning of the activity instead of an annual outlay to keep the project alive.

In UNDP's 'Millennium Development Goals, India lists out various targets as its priority to be achieved by 2015. Some of them are eradication of poverty and implementing strategies for decent and productive work for youth. These program action plans fall within the ambit of the government which is to be implemented by various ministries, NGOs, civil society organizations and UN agencies.

In an emerging market like India with its teeming 1.21 billion population and $37 \%$ of its population living below national poverty line and with the Government struggling with the soaring inflationary conditions, it is perhaps a little unreasonable to demand or even expect the government to fulfill every social responsibility. Further, with rising competition among corporations, there is now emerging a new dimension of corporate responsibility which aims at giving a corporation an edge over its competitors. It no longer means 'charity' or 'philanthropy' but is seen as an activity of 'Doing Good' with a win-win situation where the organization also derives long-term benefits from such activities.

\subsubsection{A Novel Idea}

In several instances, the pressure to find a solution to the existing problems results in what Muhammed Yunus, Nobel Laureate and founder of Grameen Bank in Bangladesh calls a 'social business enterprise' which is based on market principles but dedicated to improving the lives of the poor. The primary mission of such an enterprise 
is social development and change without compromising on the profit motive and social entrepreneurial leaders are those who facilitate these changes. One such case is he founding story of 'Magarpatta City' the vision of an INR 40-billion-township which the farmers built.

'Magarpatta City' a township was the brainchild of Satish Magar (Magar) a farmer-turned-entrepreneur who came up with this solution to the dilemma of several farmers in the city of Pune. Pune, which has developed into a metropolitan area, is located in the state of Maharashtra in western India, a mere $120 \mathrm{kms}$. away from Mumbai, the country's financial capital. Under the patronage of the Maratha Kingdom, the city earned distinctions like the Queen of the Deccan and Oxford of the East.

It was in early 1990s that Pune always a serene city, favored by educationists and pensioners saw an overwhelming growth of industry. Sectors like infrastructure especially the real estate and construction business also saw a boom. It was fast becoming an Information Technology destination along with Bangalore in the south. To accommodate this growth after 1987, the land surrounding the city and largely used for cultivation was acquired to construct residential and office buildings. Private construction firms were buying land in small plots from farmers who probably were unaware of the current market value of their land. Such land deals resulted in a mushroom growth of concrete structures in a manner which did not do much to improve urban development. To top it, the State Government did not have a policy in place to stop such practices.

India being a socialistic democracy has inheritance laws which lead to ancestral lands being fragmented when inherited from one generation to the next. Due to this factor, many farmers in this case had tiny bits of land sometimes measuring twenty feet wide and a thousand feet in length which rendered the land unviable for the use of tractors and other large equipment for agricultural practices. Moreover, the returns from such land were totally insufficient to meet the increasing cost of living of a farmer and his family. Though many farmers persisted in retaining their piece of land, several others gave up the struggle and sold them to real estate developers. To make matters worse, many farmers spent the entire sale amount received in unproductive purposes and were left in a condition worse than before.

\subsubsection{The Dilemma}

A group of about 120 farmers and their families including Magar owning four hundred acres of land between them and cultivating sugarcane were aware that they were fighting a losing battle against the real estate developers and it would be only a matter of time that their fields would be swallowed up by the concrete jungles. Their land although in an agricultural zone was part of the Pune Municipal Corporation from 1960. The Corporation's Draft Development Plan in 1982 had identified it as a potential urbanization zone. Under the Urban Land Ceiling Act1976 in India, the Government too had the authority to acquire it at a future date. The dilemma faced by the group was whether they were equipped for an alternative source of livelihood if they were to give up their land. Was it really a case of being 'between the devil and the deep sea'?

\subsubsection{The Win-win Solution}

The problem of losing their ancestral land loomed big over Magar and his farmer friends who toyed with several ideas including developing it as a golf course but abandoned it soon since it would have constituted a big financial risk on their part apart from considering it as a wasteful proposition. They also debated on constructing and selling residential bungalows and villas but it was found to be neither profitable nor legal in those days. In 1993, this group came up with the idea of developing their land themselves instead of selling it the developers or even opposing the idea of urban development. They decided to turn into entrepreneurs themselves and build a township with all the amenities a common Indian citizen would look for and some extra benefits like clean and unpolluted surroundings which he would crave. Thus was born the concept of 'Magarpatta City' a model township within the precedents of ever growing Pune city.

Magar and his group's first requirement were to study the Regional Town Planning Act to understand the regulations. Several meetings were held among the land owners. Since the farmers did not have any liquid assets to invest, they decided to pool their ancestral land totaling 400 acres valued then at INR 2,145 per sq. metre to form the initial investment. The original intent of registering the entity as a co-operative society under The Co-operative Societies Act 1912 was abandoned as the reality showed that this form of entity other than in few cases was not very successful in India. The reason for not doing so was "politics" as simply put by Magar. Thus the group decided to incorporate the entity 'Magarpatta City' as a joint stock company under the Companies Act 1956 with each agriculturist holding a share equitable to his land contribution in the capital fund. A board of directors was formed, and Magar, a major stakeholder with about $40 \%$ of the land was chosen to be the chairman and managing director. 
Under the enthusiastic and focused leadership of Magar, whose passion for this enterprise emerged and remained strong, the project got underway. Since the whole concept of the township was new and strange to some, there was no precedence upon which the farmers could fall back upon. The farmers had absolutely no requisite educational qualifications or skill sets to equip themselves for decisions like the capital structure, operations or even day-to-day management. Magar met Hafeez Contractor, a well-known architect in Mumbai who consented to take up the project. Along with few others he visited residential localities in San Jose and Santa Clara in the U.S.A., which had the concept of 'Walk-to work' and was convinced with the idea of having a plan with open spaces and the areas reserved for schools and utilities.

With a plan of action, the team met the then Chief Minister of Maharashtra, Sharad Pawar and the then Secretary, Urban Planning, D.T. Joseph who initially were skeptical to the idea but later interacted with the farmers to understand their concept better. But the entire exercise was far from smooth sailing. The absence of any policy or documentation made things going tough. Though the major capital contribution came in the form of land, funds was required at every stage, even to maintain an office. The zealous farmer-promoters skimped on expenses. Many brought in their tractors to level the land and others spent their time learning new trades and skills required for the township.

One of the early hurdles was in the form of a statute called Urban Land Ceiling Act which decreed that no individual or company in India could own land exceeding one thousand square metres. The fear of their plan being challenged by any member of the public in a court of law was a daunting prospect to the farmers and needed a waiver in this respect for their company. Though Magar was acquainted with certain individuals who had to power to help him overcome the legal hurdles, the team decided not to skip any of the mandated formalities for obtaining the requisite approval. Magar's knowledge of legal matters too helped the company get the required notification after an initial struggle. To add to their woes, the late 1990s saw a big slump in the real estate sector in India. But 'Magarpatta City' promoters had absolutely no option but to continue the township planning since they had made a public announcement and a commitment to the buyers. But it took seven long years before this and many other hurdles were finally crossed, enabling them to commence the work in the year 2000.

To turn this dream into reality, Magar approached Housing Development and Finance Corporation (HDFC) with a loan request of INR1billion. Despite having no financial knowledge to speak of or the backing of any consultants to speak on their behalf and with no concrete plan for servicing the loans, the conviction of the promoter-farmers paid off and they were granted an initial amount of INR 20 million. At a later date, it was planned to plough back the sale proceeds from the residential buildings which would be used for further construction. The total investment apart from that in land was to the tune of INR 891 million which included both short and long term debts.

The test of cooperation came in getting the second generation of the farmer families involved in the project. The core team headed by Magar would gather the youth from the families and allot them projects/work according to their interests and aptitude. The National Institute of Construction saw many of their youth who went to acquire a formal education. The farmer-promoters instead of hiring builders, turned contractors and supplied sand and other materials other than cement, steel and high quality glass themselves. The work included landscaping and road building and these youth soon realized that the money earned in these activities which was approximately INR 750 per day surpassed the income they would have ever dreamt of earning in agriculture. The intention of the promoters was not to treat the youngsters as employees but as budding entrepreneurs. The promoters decided that the township would have a theme of 'Rutu Chakra', a concept depicting the eternal time wheel of nature and are representations of five forces of nature which Indians worship.

Keeping the matter of sustenance of the farmer-promoters, the residential buildings were sold to individuals and the proceeds were divided amongst themselves. The farmers were convinced that if they were to sell their agricultural land in its present condition, they would be able to garner only $15 \%$ of the revenue of what could otherwise be earned on the sale of constructed residential buildings. A study of their cost calculation revealed that thirty per cent of the sale proceeds of residential buildings would be treated as the cost of the land. Thus the return on the investment to the farmers was embedded in the selling price of the property.

After the completion of the first building, it was unfortunately found that buyers were not eager to own a residence in that neighborhood. This led to the decision to develop other infrastructure facilities to make it an attractive proposition to the buyers. Their enthusiastic sales team pitched in with hoardings and bill boards which said 'buy a house, get a city free.' They also held a job fair for the IT Park in the year 2000and co-branded with HDFC which helped in giving a big boost to their sales. 
The first IT Park 'Cybercity Magarpatta' which became operational in 2003 is an asset created for the landowners. Unlike in the case of the residential accommodation, these office buildings have been leased out to various corporate houses which have resulted in a steady stream of revenues and the lease rent received is later distributed in the form of dividends among the land owners. Other activities of these farmer-promoters include services like the broad band, cable television, transportation system and food supply which has enabled the Magarpattacity to create a whole new generation of entrepreneurs. Magar is very emphatic when he claims that the quality of the services is par excellence.

The township has been aware of the impact of environmental degradation and has taken all steps to ensure that it contributes positively towards conservation. One such method adapted is the rain water harvesting. The pipes lie under the pavements and the soak-ways act as catchments together with the man-made central lake and such collected water is treated. The treated water is used for greening the township which has 120 acres of open land with a thirty two thousand tree cover as well as is used in residences other than for drinking purposes. To conserve scarce electricity, the township has installed solar panels which light the streets and heat water for every home while being a cost saver for the residents. 'Magarpatta city' has its own independent eco-friendly garbage disposal system where the bio-degradable waste is processed in vermiculture pits and used for gardening.

\section{2 'Magar' Impact}

Today, in 2012, the impact of all their efforts is visible. A near-perfect work-life balance has been achieved with 'walk-to work', 'walk-to-school' concept of 'Magarpatta City'. There are schools and a college too. There is a 25,000 sq.ft., gymnasium and swimming pools and eminent sports personnel coach youngsters in sports. More importantly, the farmers originally being of rural descent have integrated their lives with those of other residents. The effect of this community living is seen through the higher levels of education of children of the landowners, who were earlier only undergraduates. Each promoter owns a residence according to his capital contribution. With the current market rate of the same/similar land about INR 7,315/- per square metre or more, the wealth of the promoters has increased substantially. Higher levels of household incomes have been achieved at the rate of INR.7679.68 per annum by way of dividend from the cost from one square meter of land contributed. Many promoters have started small enterprises to cater to every day needs of the residents, be it the franchise for the cable television or running a grocery store or a bus service. In addition, they have provided employment for several others in the bargain. Magar swears that the mantra for the success is a simple three-D formula: Desire, Devotion and Dedication.

\section{Conclusion}

Satish Magar declares that he never intended the 'Magarpatta city' idea to be an act of charity or philanthropy but a thriving business enterprise with a social lining.

The case of 'Magarpatta City' an ISO 9001: 2008 certified township has successfully demonstrated that the small size of an organization is not a determinant to its success. On the other hand, another similar township 'Nanded' is being replicated in Pune on Sinhgad Road. Many urban and town planning schemes of the government are based on this idea and is showcased as a model township to other cities and town planning authorities. The reason for its activities being sustainable is its social values which are deeply embedded in its business strategy and would be a herculean task to separate one from the other. The organizational vision, its culture and more importantly the leadership has made the difference.

This brings to the forefront the essential need for a pro-active role to be played by Government and other authorities to encourage social entrepreneurship through creating an enabling environment, recognition and rewarding innovative ideas, adapting new methods in Government activities too as well as assisting in garnering new sources of funds. This would in turn nurture sustainability in organizations.

\section{References}

Austin, J., Stevenson, H., \& Wei-Skillern, J. (2006). Social and Commercial Entrepreneurship: Same, Different or Both? ET \& P, 1042-2587. Baylor University.

Defourny, J., \& Nyssens, M. (2010). Conceptions of Social Enterprise and Social Entrepreneurship in Europe and United States: Convergences and Divergences. Journal of Social Entrepreneurship, 1(1), 32-53. http://dx.doi.org/10.1080/19420670903442053

Holme, R., \& Watts, P. (2000, January). Corporate Social Responsibility: Making Good Business Sense, $W B C S D$. 
Magarpatta City: the Farmers' Cyberctiy. Retrieved from www.ibef.org

Noruzi, M. R., Westover, J. H., \& Rahimi, G. R. (2010). An Exploration of Social Entrepreneurship in an Entrepreneurship Era. Asian Social Science, 6(6).

OECD Principles of Corporate Governance. (2004). Retrieved from http://www.oecd.org/corporate/ca/corporategovernanceprinciples/31557724.pdf

Satish, M. (2010, April 10). Interview with Mr., Chairman and Managing Director, Magarpatta Township Development and Construction Company Ltd.

The amazing story of Magarpatta. Retrieved from www.rediff .com

Thompson, J., \& Doherty, B. (2006). The Diverse World of Social Enterprise. International Journal of Social Economics, 33(5/6), 361-375. http://dx.doi.org/10.1108/03068290610660643

UNDP Million Development Goals India. Retrieved from http://www.undp.org/content/india/en/home/mdgoverview/

World Commission on Environment and Development. (1987). Retrieved from www.un-documents.net/wced-ocf.htm 